\title{
A membrane filter technique for testing disinfectants
}

\author{
JEAN PRINCE 1 , C. E. A. DEVERILL, AND G. A. J. AYLiffE \\ From the Hospital Infection Research Laboratory, Birmingham
}

SYNOPSIS A membrane filter was used for assessing the surface disinfecting activity of phenolic disinfectants and a chloroxylenol disinfectant. The influence of the type of organism, inoculum size, and hardness of water was investigated. Pseudomonas aeruginosa was chosen for the standardized test. Disinfectant solutions were prepared in water of $300 \mathrm{ppm}$ hardness and applied for two and a half minutes and eight minutes to the bacteria deposited from filtration of $1 \mathrm{ml}$ of a suspension containing $10^{6}$ bacteria. The membrane filter test has certain advantages over many tests, eg, all organisms surviving after treatment can be counted and residual disinfectant is easily removed.

Membrane filtration has been used with considerable success in many branches of microbiology. The technique has been used for studying the activity of antimicrobial drugs (Meers and Churcher, 1974) and also for testing disinfectants (Prickett and Rawal, 1972). Its use offers more flexibility than most other suspension or surface tests, residual disinfectant is more readily removed, and it allows sampling of large volumes of mixtures of disinfectant and organisms.

In this study, a test is described using membrane filters for assessing the activity of phenolic disinfectants and a chloroxylenol disinfectant. An attempt has been made to evaluate the influence of various factors, eg, time of exposure to the disinfectant, inoculum size, and hardness of water, on the performance of several disinfectants.

\section{Materials and Methods}

\section{ORGANISMS}

The following organisms were used in the experiments:- Staphylococcus aureus (NCTC 9717), Escherichia coli (NCTC 8196), Proteus vulgaris (NCTC 4635), Pseudomonas aeruginosa (NCTC 6749), and Klebsiella aerogenes (JP 1970).

Freeze-dried strains were reconstituted at fourweekly intervals and maintained on nutrient agar slopes. For the tests, the organisms were grown in nutrient broth (Oxoid no. 2) for 18 hours at $37^{\circ} \mathrm{C}$. After incubation, cultures were centrifuged, washed three times in quarter strength Ringer's solution, and resuspended each time by shaking on a rota-

\footnotetext{
'Present address: Reckitt \& Colman, Hull.
}

Received for publication 30 September 1974. mixer for 15 seconds. The final suspension was standardized to approximately $10^{8}$ organisms per $\mathrm{ml}$ using a nephelometer, and viable counts were made to confirm this figure by the method of Miles, Misra, and Irwin (1938). Dilutions were made as required in quarter strength Ringer's solution. No additional organic matter was added.

\section{DISINFECTANTS}

The following were used:

A, fluid containing $4.8 \%$ chloroxylenol; B, clear soluble phenolic containing $20 \% \mathrm{v} / \mathrm{v}$ phenols and an anionic detergent; $\mathrm{C}$, clear soluble phenolic containing $40 \% \mathrm{v} / \mathrm{v}$ phenols and a synthetic detergent; $\mathrm{D}$, clear fluid containing a $16 \%$ mixture of synthetic phenols; E, clear soluble phenolic containing $50 \%$ phenols; and F, clear fluid containing $20 \% \mathrm{v} / \mathrm{v}$ xylenols and an anionic detergent.

The concentrations of disinfectants used in these tests were either the manufacturers' recommended concentrations or as determined by the capacity test (Kelsey and Sykes, 1969) and were diluted as required for each test.

\section{TECHNIQUE}

Millipore Sterifil membrane filter holders with Oxoid membrane filters of $4.7 \mathrm{~cm}$ diameter and a pore size of $0.45 \mu$ were used in the tests. One $\mathrm{ml}$ of the bacterial suspension was pipetted on the membrane, spread evenly over the surface, and the fluid was removed by filtration. The membrane was covered with $20 \mathrm{ml}$ of disinfectant, diluted in distilled water or water of the required hardness, and left for two and a half or eight minutes at room temperature. After rapid filtration of the disinfectant, 
the membrane was washed through twice with $10 \mathrm{ml}$ of nutrient broth, transferred to nutrient agar (Oxoid no. 2) containing $10 \%$ horse blood and incubated for 24 or 48 hours at $37^{\circ} \mathrm{C}$. Counts of colonies on the membranes were made using a plate culture microscope.

The following control tests were made to eliminate effects due to residual disinfectant. Filters were treated with disinfectants as in the tests, washed, and seeded with countable numbers of Staph. aureus. Counts were compared with those on washed membranes not exposed to a disinfectant. No evidence of residual activity was found in any of the tests. The effect of filtration on loss or survival of organisms was also investigated and it was found that counts on membranes seeded with Staph. aureus or Ps. aeruginosa were not influenced by varying negative pressures, or times of filtration up to one minute.

\section{Results}

TYPE OF ORGANISM

The preliminary tests on fluids $A, B$, and $D$ were made with five organisms (table I) and on fluids $C$, $\mathrm{F}$, and $\mathrm{E}$ with two organisms (table II). Although there was some variation in activity of disinfectants against the organisms tested, $P$ s. aeruginosa was one of the more resistant organisms (eg, table II with fluid F), and was used alone in most of the subsequent experiments.

INOCULUM

An initial inoculum of $10^{6}$ to $10^{8}$ organisms was considered suitable. A study was made to determine the initial count within this range which gave countable numbers of organisms in most tests after exposure to disinfectants. Counts in excess of 200 organisms are difficult to count accurately on a membrane. Suspensions of 18-hour cultures of $P S$. aeruginosa and $E$. coli were used undiluted and diluted $1 / 10$ and $1 / 100$. The tests were made with $1 \%$ disinfectant $\mathrm{B}$ and $1 \%$ disinfectant $\mathrm{C}$. The results are shown in table III. The results obtained

\begin{tabular}{|c|c|c|c|}
\hline \multirow{2}{*}{$\begin{array}{l}\text { No. of Organisms } \\
\text { on Membrane after } \\
\text { Treatment }\end{array}$} & \multicolumn{3}{|l|}{ Number of Tests } \\
\hline & Fluid $A 2.5 \%$ & Fluid B $1 \%$ & Fluid $D 1 \%$ \\
\hline \multicolumn{4}{|l|}{ Ps. aeruginosa } \\
\hline $0-\quad 10$ & 4 & 2 & 0 \\
\hline $11-100$ & 2 & 0 & 3 \\
\hline $101-1000$ & 0 & 2 & $\mathbf{0}$ \\
\hline$>1000$ & 0 & 2 & 0 \\
\hline Total tests & 6 & 6 & 3 \\
\hline \multicolumn{4}{|l|}{ E. coli } \\
\hline $0-10$ & 6 & 2 & 3 \\
\hline $11-100$ & 0 & 2 & 0 \\
\hline $101-1000$ & 0 & 1 & 0 \\
\hline$>1000$ & 0 & 1 & 0 \\
\hline Total tests & 6 & 6 & 3 \\
\hline \multicolumn{4}{|l|}{ Staph. aureus } \\
\hline $0-10$ & 4 & 2 & 3 \\
\hline $11-100$ & 2 & 0 & 0 \\
\hline $101-1000$ & $\mathbf{0}$ & 2 & 0 \\
\hline$>1000$ & 0 & 2 & 0 \\
\hline Total tests & 6 & 6 & 3 \\
\hline \multicolumn{4}{|l|}{ K. aerogenes } \\
\hline $0-\quad 10$ & 4 & 1 & 2 \\
\hline $11-100$ & 1 & 0 & 1 \\
\hline $101-1000$ & 1 & 5 & 0 \\
\hline$>1000$ & 0 & 0 & 0 \\
\hline Total tests & 6 & 6 & 3 \\
\hline \multicolumn{4}{|l|}{ P. vulgaris } \\
\hline $0-10$ & 5 & 3 & 1 \\
\hline $11-100$ & 1 & $\mathbf{0}$ & 1 \\
\hline $101-1000$ & 0 & $\mathbf{0}$ & 1 \\
\hline$>1000$ & 0 & 3 & 0 \\
\hline Total tests & 6 & 6 & 3 \\
\hline
\end{tabular}

Table I Activity of disinfectants on various organisms ${ }^{1}$ Time of exposure two-and-a-half minutes; inoculum $10^{7}$ organis diluent distilled water

on exposure of Ps. aeruginosa to fluid B we variable, but more tests with an initial count of 106 gave a countable number of organisms than wit the larger inocula. An initial inoculum of 109 organisms was therefore chosen for the final test.

HARDNESS OF WATER

In some of the disinfectant tests in current use th disinfectants are diluted in hard water. As the results. obtained from some of the preliminary tests weice better than might be expected from the Kelsey/Sykes

\begin{tabular}{|c|c|c|c|c|c|c|}
\hline \multirow{3}{*}{$\begin{array}{l}\text { Number of } \\
\text { Organisms } \\
\text { on Membrane } \\
\text { after Treatment }\end{array}$} & \multicolumn{6}{|c|}{ Number of Tests } \\
\hline & \multicolumn{3}{|l|}{ Staph. aureus } & \multicolumn{3}{|c|}{ Ps. aeruginosa } \\
\hline & Fluid C $1 \%$ & Fluid F $1 \%$ & Fluid E $1 \%$ & Fluid C $1 \%$ & Fluid F $1 \%$ & Fluid E $1 \%$ \\
\hline $0-\quad 10$ & 2 & 3 & 5 & 1 & 0 & 5 \\
\hline $11-100$ & 2 & 0 & 0 & 2 & 1 & 0 \\
\hline $101-1000$ & 1 & 0 & 0 & 2 & 1 & 0 \\
\hline$>1000$ & 0 & 0 & 0 & 0 & 1 & 0 \\
\hline Total tests & 5 & 3 & 5 & 5 & 3 & 5 \\
\hline
\end{tabular}

Table II Activity of disinfectants on Ps. aeruginosa and Staph. aureus ${ }^{1}$

${ }^{1}$ Time of exposure two-and-a-half minutes; inoculum size $10^{7}$ organisms; diluent distilled water 


\begin{tabular}{|c|c|c|c|c|c|c|}
\hline \multirow{3}{*}{$\begin{array}{l}\text { Number of } \\
\text { Organisms } \\
\text { on Membrane } \\
\text { after Treatment }\end{array}$} & \multicolumn{6}{|c|}{ Number of Tests } \\
\hline & \multicolumn{3}{|c|}{$\begin{array}{l}\text { (Inoculum size, number of organisms) } \\
\text { Ps. aeruginosa }\end{array}$} & \multicolumn{3}{|c|}{ Escherichia coli } \\
\hline & $10^{8}$ & $10^{:}$ & $10^{\circ}$ & $10^{8}$ & $10^{7}$ & $10^{6}$ \\
\hline \multicolumn{7}{|l|}{$1 \%$ Fluid C } \\
\hline $0-10$ & 3 & 3 & 8 & 3 & 5 & 6 \\
\hline $11-100$ & 1 & 4 & 1 & 0 & 1 & 0 \\
\hline $101-1000$ & 3 & 2 & 1 & 2 & 0 & 0 \\
\hline$>1000$ & 3 & 1 & 0 & 1 & 0 & 0 \\
\hline Total tests & 10 & 10 & 10 & 6 & 6 & 6 \\
\hline \multicolumn{7}{|l|}{$1 \%$ Fluid $B$} \\
\hline $0-10$ & 0 & 0 & 2 & 1 & 3 & 10 \\
\hline $11-100$ & 0 & 1 & 1 & 1 & 3 & 1 \\
\hline $101-1000$ & 0 & 0 & 3 & 4 & 4 & 0 \\
\hline$>1000$ & 7 & 6 & 1 & 5 & 0 & 0 \\
\hline Total tests & 7 & 7 & 7 & 11 & 10 & 11 \\
\hline
\end{tabular}

Table III Effect of variations in inoculum size on activity of disinfectants ${ }^{1}$

1 Time of exposure two-and-a-half minutes, diluent distilled water

capacity test results, tests using water of varying hardness were compared. Solutions of disinfectants $\mathrm{A}, \mathrm{B}$, and $\mathrm{C}$ were made in distilled water and in water of $100 \mathrm{ppm}, 200 \mathrm{ppm}$, and $300 \mathrm{ppm}$ hardness (Curl, 1956). Table IV shows that disinfectants B and $C$ were not affected by hard water. Disinfectants A shows a marked reduction in activity on increasing water hardness from 200 to $300 \mathrm{ppm}$.

\section{REPEATABILITY}

Eight tests using standardized techniques were made on three of the disinfectants by each of two workers to assess differences between operators. Comparisons were made between disinfectants A $(2.5 \%)$, B $(1.0 \%$ and $1.5 \%)$, and $\mathrm{C}(0.625 \%)$. The same batch of nutrient broth was used for all tests and for preparing nutrient agar. Results were read after
24 hours' incubation. Ps. aeruginosa (NCTC 6749) was used as the test organism and the inoculum was standardized to $10^{6}$ organisms. Disinfectants were diluted in $300 \mathrm{ppm}$ hard water and removed by filtration after two-and-a-half or eight minutes' exposure. In a second series of tests, varying concentrations of disinfectants $\mathbf{B}$ and $\mathbf{C}$ were compared.

The results shown in table $\mathrm{V}$ were more consistent than in previous experiments, and, except with disinfectant $A$, a reduction of at least $10^{4}(99.99 \%)$ was obtained in most experiments after exposure for eight minutes. The proportion of recovered organisms was significantly greater after exposure to $2.5 \% \mathrm{~A}$ than to the other disinfectants $(\mathrm{P}<0.01)$ at both two-and-a-half and eight minutes. There was also no significant difference in the proportion of recovered organisms after exposure to $1 \%$ and

\begin{tabular}{|c|c|c|c|c|c|}
\hline \multirow{3}{*}{$\begin{array}{l}\text { Disinfectant } \\
\text { and } \\
\text { Concentration }\end{array}$} & \multirow{3}{*}{$\begin{array}{l}\text { Number of } \\
\text { Organisms } \\
\text { on Membrane } \\
\text { after Treatment }\end{array}$} & \multicolumn{4}{|l|}{ Number of Tests } \\
\hline & & \multicolumn{4}{|c|}{ Hardness of Water } \\
\hline & & Distilled Water & $100 \mathrm{ppm}$ & $200 \mathrm{ppm}$ & $300 \mathrm{ppm}$ \\
\hline $\begin{array}{l}\text { Fluid A } \\
2.5 \%\end{array}$ & $\begin{array}{c}0-10 \\
11-100 \\
101-1000 \\
>1000 \\
\text { Total tests }\end{array}$ & $\begin{array}{r}11 \\
0 \\
1 \\
0 \\
12\end{array}$ & $\begin{array}{r}12 \\
0 \\
0 \\
0 \\
12\end{array}$ & $\begin{array}{r}10 \\
2 \\
0 \\
0 \\
12\end{array}$ & $\begin{array}{r}0 \\
1 \\
5 \\
6 \\
12\end{array}$ \\
\hline $\begin{array}{l}\text { Fluid B } \\
1 \%\end{array}$ & $\begin{array}{c}0-10 \\
11-100 \\
101-1000 \\
>1000 \\
\text { Total tests }\end{array}$ & $\begin{array}{l}0 \\
4 \\
1 \\
0 \\
5\end{array}$ & $\begin{array}{l}0 \\
3 \\
2 \\
0 \\
5\end{array}$ & $\begin{array}{l}1 \\
4 \\
0 \\
0 \\
5\end{array}$ & $\begin{array}{l}1 \\
4 \\
0 \\
0 \\
5\end{array}$ \\
\hline $\begin{array}{l}\text { Fluid C } \\
0.625 \%\end{array}$ & $\begin{array}{c}0-10 \\
11-100 \\
101-1000 \\
>1000 \\
\text { Total tests }\end{array}$ & $\begin{array}{l}1 \\
4 \\
0 \\
0 \\
5\end{array}$ & $\begin{array}{l}3 \\
2 \\
0 \\
0 \\
5\end{array}$ & $\begin{array}{l}2 \\
3 \\
0 \\
0 \\
5\end{array}$ & $\begin{array}{l}2 \\
3 \\
0 \\
0 \\
5\end{array}$ \\
\hline
\end{tabular}

Table IV Effect of hardness of water on the activity of disinfectants on Ps. aeruginosa

${ }^{1}$ Time of exposure two-and-a-half minutes; inoculum size $10^{\circ}$ organisms 


\begin{tabular}{|c|c|c|c|c|c|c|c|c|}
\hline \multirow{4}{*}{$\begin{array}{l}\text { Number of } \\
\text { Organisms } \\
\text { on Membrane } \\
\text { after Treatment }\end{array}$} & \multicolumn{8}{|c|}{ Number of Tests } \\
\hline & \multicolumn{8}{|c|}{ Time of Exposure (minutes) } \\
\hline & $2 \frac{1}{2}$ & 8 & $2 \frac{1}{2}$ & 8 & 23 & 8 & $2 \frac{1}{2}$ & 8 \\
\hline & \multicolumn{2}{|c|}{ Fluid B $1 \%$} & \multicolumn{2}{|c|}{ Fluid B $1.5 \%$} & \multicolumn{2}{|c|}{ Fluid C $0.625 \%$} & \multicolumn{2}{|c|}{ Fluid A $2.5 \%$} \\
\hline $0-\quad 10$ & 9 & 11 & 8 & 11 & 6 & 13 & 0 & 0 \\
\hline $11-100$ & 4 & 4 & 6 & 4 & 6 & 3 & 1 & 1 \\
\hline $101-1000$ & 2 & 1 & 2 & 1 & 4 & 0 & 5 & 4 \\
\hline$>1000$ & 1 & 0 & 0 & 0 & 0 & 0 & 10 & 11 \\
\hline Total tests & 16 & 16 & 16 & 16 & 16 & 16 & 16 & 16 \\
\hline
\end{tabular}

Table V Standard test of the activity of disinfectants against Ps. aeruginosa ${ }^{1}$

${ }^{1}$ Inoculum size $10^{6}$ organisms; diluent $300 \mathrm{ppm}$ hard water

\begin{tabular}{|c|c|c|c|c|c|c|}
\hline \multirow{3}{*}{$\begin{array}{l}\text { Numbers of } \\
\text { Organisms } \\
\text { on Membrane } \\
\text { after Treatment }\end{array}$} & \multicolumn{6}{|c|}{ Number of Tests } \\
\hline & \multicolumn{6}{|c|}{ Time of Exposure (min) } \\
\hline & $\begin{array}{l}\text { Fluid } C \\
\text { Concentr ation }\end{array}$ & 21 & 8 & $\begin{array}{l}\text { Fluid } B \\
\text { Concentration }\end{array}$ & $2 \frac{1}{2}$ & 8 \\
\hline $\begin{array}{r}0-10 \\
11-100 \\
101-1000 \\
>1000 \\
\text { Total tests }\end{array}$ & $1 \%$ & $\begin{array}{r}6 \\
7 \\
3 \\
0 \\
16\end{array}$ & $\begin{array}{r}14 \\
2 \\
0 \\
0 \\
16\end{array}$ & $2 \%$ & $\begin{array}{r}9 \\
6 \\
1 \\
0 \\
16\end{array}$ & $\begin{array}{r}15 \\
1 \\
0 \\
0 \\
16\end{array}$ \\
\hline $\begin{array}{c}0-10 \\
11-100 \\
101-1000 \\
>1000 \\
\text { Total tests }\end{array}$ & $0.625 \%$ & $\begin{array}{r}3 \\
11 \\
2 \\
0 \\
16\end{array}$ & $\begin{array}{r}13 \\
3 \\
0 \\
0 \\
16\end{array}$ & $1 \%$ & $\begin{array}{r}2 \\
6 \\
6 \\
2 \\
16\end{array}$ & $\begin{array}{r}6 \\
8 \\
1 \\
1 \\
16\end{array}$ \\
\hline $\begin{array}{c}0-10 \\
11-100 \\
101-1000 \\
>1000 \\
\text { Total tests }\end{array}$ & $0.5 \%$ & $\begin{array}{r}1 \\
12 \\
2 \\
1 \\
16\end{array}$ & $\begin{array}{r}12 \\
4 \\
0 \\
0 \\
16\end{array}$ & $0.75 \%$ & $\begin{array}{r}1 \\
2 \\
5 \\
8 \\
16\end{array}$ & $\begin{array}{r}4 \\
7 \\
5 \\
0 \\
16\end{array}$ \\
\hline $\begin{array}{r}0-\quad 10 \\
11-100 \\
101-1000 \\
>1000 \\
\text { Total tests }\end{array}$ & $0.3 \%$ & $\begin{array}{r}0 \\
3 \\
1 \\
12 \\
16\end{array}$ & $\begin{array}{r}8 \\
6 \\
2 \\
0 \\
16\end{array}$ & $0.5 \%$ & $\begin{array}{r}1 \\
0 \\
3 \\
12 \\
16\end{array}$ & $\begin{array}{r}1 \\
2 \\
3 \\
10 \\
16\end{array}$ \\
\hline
\end{tabular}

Table VI Effect of varying concentrations of fluids $B$ and $C$ on Ps. aeruginosa ${ }^{1}$

${ }^{1}$ Inoculum size $10^{6}$ organisms; diluent $300 \mathrm{ppm}$ hard water

$1.5 \% \mathrm{~B}$ and $0.625 \% \mathrm{C}$. The results of the two individual operators are combined in table $\mathrm{V}$ since no consistent differences between operators were obtained, although one operator had significantly higher results at two-and-a-half minutes. Variations in numbers of survivors after exposure to different concentrations of $\mathbf{B}$ and $\mathrm{C}$ are shown in table VI. The concentrations of $\mathrm{C}$ showed significantly different results between $0.5 \%$ and $0.3 \%$ at both two-anda-half and eight minutes. Significant differences were found between all concentrations of $B$ at two-anda-half minutes but not between $0.75 \%$ and $1.0 \%$ at eight minutes. Reductions of approximately $10^{4}$ were obtained in most tests with concentrations of $0.5 \%$ and $0.625 \% \mathrm{C}$ at two-and-a-half minutes, and $1 \% \mathrm{~B}$ at eight minutes but not at two-and-a-half minutes.

\section{Discussion}

Preliminary studies on membrane filters for testin disinfectants suggest that a reproducible test can be developed. Residual disinfectant can be easiln removed and the method should be particularlw useful for testing disinfectants which are difficult to neutralize (Bergan and Lystad, 1972). The technique should also be useful as a screening test for surface disinfection, since none of the survivors are washe off when the disinfectant is removed, and any detergent effect associated with the disinfectant is

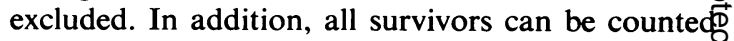
without the use of an additional sampling method $\vec{D}$ The test is flexible, and times and other conditionso may be readily varied depending on requirements. An exposure time of two-and-a-half minutes waso 
initially selected, since this seemed to be a reasonable time for surface disinfection. However, as the reduction in organisms obtained in the preliminary tests was often inadequate at two-and-a-half minutes and there was some inconsistency with fluid $B$ at two-and-a-half minutes, eight minutes was chosen in the later tests to correspond with the time of exposure for each stage of the Kelsey-Sykes capacity test.

The number of organisms on various surfaces under different conditions is difficult to assess, but unless gross contamination is present, pathogens are probably rarely found in excess of $10^{6}$ on an area corresponding to a membrane filter. The effectiveness of the test is judged by the percentage reduction in viable organisms and the number of surviving organisms remaining after the disinfection process. If a reduction of $10^{4}(99.99 \%)$ or $10^{5}$ is considered to be satisfactory, $10^{1}-10^{2}$ organisms would survive disinfection, ie, approximately 0.6 to 6.0 organisms per sq $\mathrm{cm}$ of surface. The criteria for recommending a dilution of a disinfectant for use on the basis of an in-vitro test are difficult to define. Disinfectant B was tested by the membrane filter technique because results of in-use tests were already available (Prince and Ayliffe, 1972). These results and use dilutions for clean and dirty conditions, as indicated by the Kelsey-Sykes capacity test, are included with the membrane filter results in table VII. In in-use tests, $16 \%$ of samples of disinfectant B showed contamination at or above the recommended use dilution for clean conditions, and the membrane filter test showed a reduction of $10^{4}$ at eight minutes in $91 \%$ of the tests. Other membrane filter tests with $1 \%$ disinfectant $B$ were unsatisfactory. However, at $2 \%, 0 / 20$ samples of the disinfectant were contaminated in in-use tests and $94 \%$ showed a reduction of
$10^{5}$ at eight minutes. Another phenolic disinfectant (C), used in some hospitals, showed a reduction of $10^{5}$ in $81 \%$ tests when used at the concentration recommended for clean conditions. Further tests using other organisms and disinfectants as well as more in-use tests will probably be required if the test is to be used for these purposes.

Disinfectant A showed greater activity in the preliminary tests than in the tests for repeatability. This was mainly due to differences in the hardness of water in the two tests. The preparation was less active when water of a hardness of $300 \mathrm{ppm}$ was used. This concentration was used in the test so that results could be compared with other existing tests, eg, the Kelsey-Sykes capacity test. Nevertheless, it is possible that this degree of hardness is too high for a screening test and that the recommended concentration of $\mathbf{A}$ would be adequate for disinfection of most clean surfaces.

Tests were made at room temperature although the technique could be adapted for use at varying temperatures if required. An excess of disinfectant was used and testing of variations in volume was unnecessary. Standardization of protein presented some difficulties and has been excluded from the present test system, but development of the test could include organic matter. In-use tests are required to assess disinfectants under practical conditions (Kelsey and Maurer, 1969; Prince and Ayliffe, 1972). Since cleaning with soap and water or detergent is so effective (Ayliffe, Collins, and Lowbury, 1966), surface disinfection should rarely be required. However, large amounts of disinfectants are still used in hospitals for disinfecting surfaces and a reasonably reproducible screening test which can be used alone or with tests on organisms in suspension should be of value in deciding whether a

\begin{tabular}{|c|c|c|c|c|c|c|c|c|c|}
\hline \multicolumn{3}{|c|}{ Capacity Tests } & \multicolumn{3}{|c|}{ Membrane Filter Tests } & \multirow{2}{*}{\multicolumn{2}{|c|}{$\begin{array}{l}\text { Percentage } \\
\text { Tests Showing } \\
\text { Reductions of }\end{array}$}} & \multicolumn{2}{|l|}{ In-use Tests } \\
\hline \multirow[t]{2}{*}{ Disinfectant } & \multicolumn{2}{|c|}{$\begin{array}{l}\text { Recommended } \\
\text { Concentration }\end{array}$} & \multirow{2}{*}{$\begin{array}{l}\text { Number } \\
\text { of } \\
\text { Tests }\end{array}$} & \multirow{2}{*}{$\begin{array}{l}\text { Concentra- } \\
\text { tion }\end{array}$} & \multirow{2}{*}{$\begin{array}{l}\text { Time of } \\
\text { Exposure } \\
\text { (min) }\end{array}$} & & & \multirow{2}{*}{$\begin{array}{l}\text { Concentra- } \\
\text { tion }\end{array}$} & \multirow{2}{*}{$\begin{array}{l}\text { Number of } \\
\text { Samples } \\
\text { Showing } \\
\text { Contamina- } \\
\text { tion }\end{array}$} \\
\hline & Clean & Dirty & & & & $10^{4}$ & $10^{5}$ & & \\
\hline $\mathbf{A}$ & $5 \%$ & $*$ & 16 & $2.5 \%$ & $\begin{array}{l}2 \frac{1}{2} \\
8\end{array}$ & $\begin{array}{l}6 \\
6\end{array}$ & $\begin{array}{l}0 \\
0\end{array}$ & - & - \\
\hline $\mathbf{B}$ & $1 \%$ & $2 \%$ & $\begin{array}{l}32 \\
16\end{array}$ & $\begin{array}{l}1 \% \\
2 \%\end{array}$ & $\begin{array}{l}2 \frac{1}{2} \\
8 \\
2 \frac{1}{2} \\
8\end{array}$ & $\begin{array}{r}66 \\
91 \\
94 \\
100\end{array}$ & $\begin{array}{l}34 \\
53 \\
56 \\
94\end{array}$ & $\begin{array}{l}0.9-1.9 \% \\
2.0 \% \& \text { ove }\end{array}$ & $\begin{array}{l}5 / 35 \\
0 / 20\end{array}$ \\
\hline C & $0.625 \%$ & $1 \%$ & $\begin{array}{l}32 \\
16\end{array}$ & $\begin{array}{l}0.625 \% \\
1 \%\end{array}$ & $\begin{array}{l}2 \frac{1}{2} \\
8 \\
2 \frac{1}{2} \\
8\end{array}$ & $\begin{array}{r}81 \\
100 \\
81 \\
100\end{array}$ & $\begin{array}{l}28 \\
81 \\
38 \\
88\end{array}$ & - & - \\
\hline
\end{tabular}

Table VII Comparison of capacity, membrane filter, and in-use tests

* = not recommended

- = none tested 
disinfectant has sufficient range of activity, and for indicating a preliminary dilution for its use. Since a membrane filter is not a typical surface, further tests comparing the membranes with other surfaces are still required.

These preliminary tests with membrane filters have shown that the technique can give reasonably repeatable results. The technique could be further developed or incorporated in existing tests to become a useful tool both in quality control and development work in the disinfectant industry as well as for hospitals.

\section{References}

Ayliffe, G. A. J., Collins, B. J., and Lowbury, E. J. L. (1966). Cleaning and disinfection of hospital floors. Brit. med. J., 2, 442-445.

Bergan, T., and Lystad, A. (1972). Evaluation of disinfectant inactiva tors. Acta path. microbiol. scand., Sect. B, 80, 507-510.

Curl, L. F. (1956). Interpretation 21, Regulations for the Enforcemento of the Federal Insecticide, Fungicide, Rodenticide Act. Agricultural Research Service, U.S. Department of Agriculture Federal Register 21, 7020.

Kelsey, J. C., and Maurer, I. M. (1966). An in-use test for hospita disinfectants. Mth. Bull. Minist. Hlth Lab. Serv., 25, 180-184. @

Kelsey, J. C., and Sykes, G. (1969). A new test for the assessment of disinfectants with particular reference to their use in hospitals.? Pharm. J., 202, 607-609.

Meers, P. D., and Churcher, G. M. (1974). Membrane filtration in the? study of antimicrobial drugs. J. clin. Path., 27, 288-291.

Miles, A. A., Misra, S. S., and Irwin, J. D. (1938). The estimation of the bactericidal power of the blood. J. Hyg. (Lond.), 38, 732-749.

Prickett, J. M., and Rawal, B. D. (1972). Membrane filtration method for the evaluation of quaternary ammonium disinfectants. Lab. Pract., 21, 425-428.

Prince, J., and Ayliffe, G. A. J. (1972). In-use testing of disinfectants in hospitals. J. clin. Path., 25, 586-589. 